\title{
Deixis Analysis of the Good Dinosaur the Movie
}

\author{
Nur Kholis \\ Sekolah Indonesia, Kuala Lumpur. \\ Cool.alcukil@gmail.com
}

\begin{abstract}
This essay is a descriptive qualitative research which will attempt to answer the following objectives: (1) what are types of deixis found in the movie of "The Good Dinosaur"? And (2) what is the most dominant deixis found in the movie "The Good Dinosaur" and the analysis?

From the analysis of the movie entitled "The Good Dinosaur", found some data finding about the types of deixis which used in the movie. Five types of deixis they are: personal deixis, time deixis, place deixis, social deixis, and discourse deixis found in the film in the different data percentage. Personal deixis found in the highest percentage which directly answers the second objective with the data collection $80 \%$, time deixis $5 \%$, place deixis $3 \%$, social deixis $9 \%$ and discourse deixis $3 \%$.

Personal deixis has a correlation to the point of view of narrating the film "The Good Dinosaur". This caused by the finding of personal deixis involving thr first, second and third pronoun in determining the story. Further, this contribute to make the personal deixis dominate the deixis used in the film.
\end{abstract}

Key Words: Deixis, Types of deixis, Personal deixis.

\section{Abstrak}

Karangan ini merupakan sebuah penelitian deskriptif qualitatif yang akan mencoba menjawab rumusan masalah: (1) Jenis-jenis deiksis apakah yang ditemukan dalam film yang berjudul "The Good 
Dinosaur"? dan (2) Apakah jenis deiksis yang dominan ditemukan dalam film "The God Dinosaur" serta analisisnya?.

Dari analisis film yang berjudul "The Good Dinosaur", ditemukan beberapa penemuan data tentang jenis-jenis deiksis yang digunakan dalam film. Lima jenis deiksis yakni deiksis persona, deiksis waktu, deiksis tempat, deiksis social dan deiksis wacana ditemukan dalam film dengan persentase data yang berbeda-beda. Deiksis persona ditemukan dalam persentase tertinggi yang sekaligus menjawab pertanyaan kedua dengan perolehan data sebesaar $80 \%$, deiksis waktu sebesar 5\%, deiksis tempat sebesar 3\%, diksis social sebesar $9 \%$ dan deiksis wacana sebesar 3\%.

Deiksis persona memiliki keterkaitan dengan sudut pandang penceritaan dalam film 'The Good Dinosaur". Hal ini dikarenakan hasil penemuan deiksis persona yang melibatkan kata ganti pertama, kata ganti kedua dan kata ganti ketiga memiliki dalam menentukan jalan cerita. Hal ini kemudian mendasari kenapa deiksis persona mendominasi deiksis yang digunakan dalam film.

Kata Kunci: Deiksis, Macam-macam deiksis, Persona deiksis

\section{Introduction}

Language is a tool to communicate between the speaker and the partner of speaking in the daily activity which has its own meaning and purpose. In the communication, language plays the most important thing to transfer and deliver the meaning to the hearer. To transfer it, well we know the name of verbal communication and written communication. Both of the kind of communication has their basic function of language tend to the need of the people to use the language in communication. Some of the functions of language are to express the feeling, to communicate, as a tool to make an integration and social adaptation in a particular environment and situation and also as the tool for social control (Keraf, 1997:3). 
Deals to pragmatic in a language, Leech (1983:14) explain in his opinion that "pragmatic deals with verbal acts and performances which take place in particular situation, in time". As a part of language, pragmatic, which since 1938 had been acknowledged to be the new room of linguistics study, plays a fundamental role in studying the verbal acts in a particular performance and situation. Thus, pragmatic is a study of the ability of the language user in combining and adapting sentence correctly (Yuliana, 2011:1). As the part of language which also means as a study of language that involves the aspects in the outside of language, pragmatic has its own scope. Based on Gazdar (1979:2), pragmatics is the study of deixis (at least in a part), implicature, presupposition, speech acts and aspect of discourse structure.

Based on the explanation of Gazdar, the brief explanation of those studies in pragmatics, when the language focuses on how the hearer could response and answers explicitly the questions of the questioner with some non literal word of answer, the study of pragmatic is divined as implicature. However, if the hearer can give a response with some additional meaning such as some assumptions, the study named as presupposition. Further, Levinson in Suyono (1990:5) a linguist define other part of pragmatic namely speech acts that according to him, communication is not only a symbol, word or sentence but it is more appropriate to be called as a the result of those which forms a behavior of speech act, which this is also studied in the pragmatic. Another part of pragmatic is deixis that could be meant as a condition in semantic which exist in a sentence or utterance in which 
only could be interpreted the reference with considering the context of speaking or sentence.

In this occasion, during the fulfilling of the paper, the writer interested to raise the study of pragmatic which deals to the reference that considering the context of speaking to be interpreted: Deixis. Deixis in a communication plays some important matters to refer who or what the object is being talked about. Deixis is a part of language which always present both in daily communication and in the text or discourse. As what Yule (1996:1) stated, "the technical term for one of the most basic things we do with utterances which means pointing is called deictic expression.

To analyze those explanations of deixis, the writer tries to analyze it from the very good movie namely "The Good Dinosaurs" movie directed by Peter Sohn. The Good Dinosaur is a 2015 American 3 D computer animated comedy drama adventure buddy film produced by Pixar Animation Studios and distributed worldwide by Walt Disney Pictures, directed by Peter Sohn from a screenplay by Meg LeFauve. Set on a fictional Earth in which dinosaurs never went extinct, the film follows a young Apatosaurus named Arlo, who meets an unlikely human friend while traveling through a harsh and mysterious landscape. Bob Peterson, who came up with the idea for the story, directed the film until August 2013. In October 2014, Sohn was announced as the new director. The film, along with Inside Out, marks the first time that Pixar has released two feature films in the same year. The Good Dinosaur premiered on November 10, 2015 in Paris, and was released in the United States on November 25, 2015, to positive reviews. The 
film grossed \$329.1 million worldwide - lowest for a Pixar film - on a \$175-200 million budget.

This film is directed by Peter Sohn, an American animator, director, voice actor, and storyboard artist at Pixar Animation Studios. Sohn started his career with Pixar in the art and story departments for Finding Nemo. He also worked on The Incredibles, Ratatouille and WALL-E. Sohn also performed the voice of Emile in Ratatouille. He made his directorial debut with the short film Partly Cloudy in 2009 which he also wrote. Partly Cloudy was included in the Animation Show of Shows in 2009. Sohn co-directed the English-language version of Ponyo on the Cliff by the Sea in 2009 with John Lasseter and Brad Lewis. Sohn was directing for about 18 film which as the production of Pixar and other studios. Some of the films directed by Sohn are Monster University, Toy Story, Up and The Good Dinosaurs.

A very important thing to do during watching the movie is following the plot so that the viewer could catch the story. Plot could be met by scene per scene with the dialogue that tells us the story. Thus, because of the dialogue per scene contains its own discourse that stated by the actors that possibly to be analyzed the writer propose the paper under the title "Deixis Analysis of The Good Dinosaur Movie Directed by Peter Sohn: Pragmatic's Study”.

\section{Synopsis of the Movie}

In an alternate timeline, the asteroid that would have caused the extinction of the dinosaurs 65 million years ago passes safely over Earth. Millions of years later, two Apatosaurus named Henry and Ida, 
who are farmers, watch as their three eggs hatch into children: Libby, Buck, and the runt Arlo. Unlike his siblings, Arlo has trouble adjusting to farm life; while the others are successful and allowed to "make their mark" (a mud-print on the family's corn silo), Arlo's timid nature makes even his simple tasks difficult for him, so Henry attempts to give Arlo a sense of purpose by putting him in charge of guarding their silo from critters, and helps him set up a trap. The trap manages to capture a feral cave boy, but Arlo doesn't have the heart to kill him, and sets him free. Disappointed, Henry takes Arlo to track the cave boy, leading them into a ravine where it begins to rain. Arlo injures himself, and Henry decides to turn back, but a massive flash flood occurs, and Henry only manages to save Arlo before being swept away and killed.

Without his father, Arlo must shoulder more of the workload. He spots the same cave boy inside the silo and, blaming him for his father's death, chases him until both of them fall into a river. Arlo cannot swim, and is quickly swept downstream where he hits his head on a rock and is knocked unconscious. Waking up, he is dismayed to find himself far from home and tries to survive on his own with minimal success, becoming trapped when a boulder pins down his leg. Arlo awakes to find his leg has been freed, and the cave boy appears with food for him to eat. The cave boy then leads Arlo to a berry tree, where the cave boy fends off a large snake, amazing Arlo, and also impressing a nearby Styracosaurus, who wants to keep the boy. The eccentric older dinosaur forces Arlo to compete with him to give the boy a name he will respond to, which Arlo finally wins when he calls him "Spot", and the Styracosaurus relents. Arlo and Spot bond, as 
Arlo laments his lost family, and Spot reveals that his own parents are dead. When a thunderstorm strikes, though, Arlo runs away in fear, and loses the riverbank he has been following home.

The next morning, Arlo wakes up to find Spot at his side. They are noticed by a band of pterodactyls that appear to be conducting a rescue operation but turn out to be savagely carnivorous. When the pterodactyls try to take Spot, Arlo and Spot flee, happening upon a pair of Tyrannosaurus named Nash and Ramsey, who ward off the pterodactyls. Nash, Ramsey, and their father Butch have lost their herd of longhorns, so Arlo offers Spot's help in sniffing them out. They locate the herd, but Butch recognizes the work of cattle rustlers, and uses Arlo as a lure. Arlo and Spot attract the attention of the rustlers allowing Butch and his family to attack. During the fight, Arlo musters his courage and fends off two raptors that have overwhelmed Butch, helping to turn the fight in their favor. Having gained their respect, Arlo joins the T. Rexes in driving the cattle south when he sees the familiar mountain peaks of his homeland in the distance, and leaves with Spot to return home. Along the way, Arlo and Spot encounter an adult feral caveman in the distance, and though Spot shows interest, Arlo dissuades him and they continue on.

As another storm approaches, the pterodactyls return and attack, this time managing to carry Spot away. Arlo becomes entangled in some vines, where he has a vision of Henry leading him back home. Arlo instead resolves to save Spot, making the vision of his father proud before he fades away. Arlo wakes up filled with determination and finds and attacks the pterodactyls, which have cornered Spot at the river. Arlo and Spot manage to overpower the pterodactyls, plunging 
them one after another into the water where they are swept helplessly downstream. Another flash flood occurs, triggering a massive torrent to approach. Despite his fear, Arlo leaps into the water to rescue Spot as the two are swept away toward a waterfall. Arlo protects Spot as the two falls, and carries him to shore.

As they approach Arlo's home, the two again hear the unknown caveman call, and are approached by an entire caveman family. With great reluctance, Arlo pushes Spot to join his kind, and the two of them share a tearful goodbye. Arlo finally arrives back home to his mother and siblings, and makes his mark on the silo between those of his mother and father.

\section{Film as a Literacy Media}

Nowadays, technology has been long developed. Literacy resources could not only be found by the reading habit but trough many resources that also involve another part of senses such like visual, audio and the combination of both visual and audio. Even of course the use of reading habit is the main resource to acquire the information.

Film also called a movie, motion picture or photoplay as described by Wikipedia (2016, Retrieved may $12^{\text {th }} 2016$ ) is a series of still images which, when shown on a screen, creates the illusion of moving images due to the phi phenomenon or optical illusion. In recent, the use of a movie is not just as an entertainment to amuse the viewer, but also useful for education. Quoted from Tempo (2016, Retrieved May 12 $2^{\text {th }}$ 2016), there are six ways to build science literacy which one of them was trough film. Moreover, Noves (2000) in 
Tempo stated that study of science should be fun, and the way to make it happen is by movies. This kind of learning tyle has been applied for the student university in Brazil where there, they study science by referring to such scientific movies such like Star Wars, A Space Odyssey, Star Trek and others. This shows us that the existence of movie, now becomes the alternative ways to educate the students and largely people.

Film literacy as explained by The West Georgia University in westga.edu (Retrieved May 12 $2^{\text {th }}$ 2016) is a convergence of the interdisciplinary practices of literary and media studies, which both concentrate on the analysis of significance in all manner of texts: visual and written. Ushering students toward a more open notion of literary discourse and practice, critical media pedagogy begins with the assumption that visual images, songs, advertisements, and film are inherently ideological and political. The media enacts, as John Berger, an art critic frames it as the ways of seeing that can effectively produce and determine the meanings and outcomes of discourse itself and which, therefore, shape the cultural contexts.

John Berger according to make film as one of media reference proposed on his script entitled Ways of Seeing (1972) that described by West Georgia University in his westga.edu (Retrieved May $12^{\text {th }}$ 2016) 3 core concepts of media literacy that can be applied to films as follow:

1. Representations and images in media catalogue or mirror commonly shared practices, ideologies and experiences. In this sense, media representations play a formative role in reifying and entrenching cultural practices and are seen to be expressions, often, 
of the collective (or dominant) will. An advertisement, for example, might project gendered, classist, and even racial fears or fantasies; a film might catalogue the beliefs, assumptions, and prejudices of a particular historical moment.

2. To draw from Henry Giroux, one of todays leading critical pedagogy scholars, The media enacts its own invisible pedagogy. Media is not neutral terrain but rather contains embedded arguments, points of view, and messages.

3. According to Maurice E. Stevens, in an article on Spike Lees Malcolm X, the visual medium is an arbiter of identities. Hence more than merely reflecting shared beliefs, customs and value-systems by which we come to identify ourselves, the media plays a critical role in constructing identities and social ideology, promoting, challenging, and mediating prevailing attitudes toward corporeality, race, gender, class, sexuality, occupation, (etc.) that permeate Western culture and language at their deepest levels.

\section{Deixis in Pragmatics}

Deixis deals with connections between discourse and the situation in which discourse is used. The term of 'deixis' is derived from the Greek word which mean 'to show' or 'to indicate' used to denote the elements in a language which refer directly to the situation. Moore (2001:14) give definition about deixis that "Deixis is an important field of language study in its own right and very important for learners of languages. But it has some relevance to analysis of conversation and pragmatics. It is often and best described as "verbal pointing", that 
is to say pointing by means of language. The linguistic forms of this pointing are called deictic expressions, deictic markers or deictic words; they are also sometimes called indexicals."

Moreover, deixis is a technical term (from Greek) for one of the most basic things we do with utterance. Or it can be said 'pointing' via language. Essentially language, deixis concerns with the ways in which the interpretation of utterance depends on the analysis of that context of utterance.

Here are the explanations of five kinds of deixis as proposed by Levinson:

\section{a. Person Deixis}

In many languages, person deixis can also contain other meaning elements like the gender of the third person. In addition, to pronoun and agreeing predicates, person, or participant-role is marked in various other ways. Person deixis concerns with the encoding of the role of participants in the speech even in which the utterance in question is delivered. Yule (1996, p.9-10) describe that person deixis involves the speaker and the addressee and operates in a basic three-part division they are:

1) First person (I). The first person deixis is a reference that refers to the speaker or both speaker and referent grouped with the speaker which is expressed in singular pronouns (I, me, myself, mine) and plural pronouns (we, us, ourselves, our, ours). The first person deixis can be divided into exclusive first person deixis, which refers to a group including addressee. 
2) Second person (you). The second person deixis is a deictic reference to a person or persons identified as addressee, such as you, yourself, yourselves, your, yours.

3) Third person (He, She, It). Third person deixis is a deictic reference to a referent(s) not identified as the speaker or addressee and usually imply to the gender that the utterance refers to, for example: he, she, and they, him, himself, her, herself.

\section{b. Place deixis}

Is also described as spatial deixis, where the relative location of people and things is being indicated. Place deixis or spatial deixis usually expressed in this, these, there, here, that, and those. Place deixis can be described along many of the same parameters that apply to the time deixis. Therefore, those references to place can be absolute or relational in nature. Grundy (2000) add that there are three degrees of proximity is by no means uncommon, with some languages distinguishing proximity to the speaker and to the addressee. They are: here (proximal), there (distal), where (and the archaic hither, hence, thither, thence, wither, whence), left, right, up, down, above, below, in front, behind, come go, bring, and take.

Briefly, place deixis is an expression used to show the location relative to the location of a participant in the speech even.

\section{c. Time deixis}

Place deixis is also called as temporal deixis. Renkema (1993, p.79) stated that time deixis is a reference to time relative to a temporal reference point and it is typically the moment of 
utterance. These language resources are the adjectives of time in the line yesterday, now and tomorrow, and the verb tenses. The verb sometimes also has another function besides referring to a specific time.

For example:

A: I live here now

B: I live there now

The present tense is the proximal form as in (a) and the past tense is distal form as in (b). The deictic items use reference that can only be determined in relation to the time of the utterance in which they occur. Such as:

This / last / next Monday / week / month / year.

Now, then, ago, later, soon, before.

Yesterday, today, tomorrow.

In other words, time deixis is an expression in relation to point to certain period when the utterances produced by the speaker.

\section{d. Social deixis}

Social deixis does not deal with three main components (person, place and time) of the coordinate system of subjective orientation, but they show how different social rankings and the participants of communication utter relationships within society via language. It is rather to refer to the level of relationship between people than to information.

Levinson (1983, p.90) stated that social deixis concerns with the aspects of sentences which reflect or establish or determined 
by certain realities of participants or the social situation in which the speech event occurs. He adds that there are two basic kinds of social deixis information that seems to be encoded in language around the world. They are: Relational social deixis and Absolute social deixis. Relational social deixis is a deictic reference to some social characteristic of referrent apart from any relative ranking of referents or deictic reference to a social relationship between the speaker and addressee. In English, relational social deixis may be a lexical items (e.g. my husband, teacher, cousin, etc), pronouns (you, her). Absolute social deixis is a deictic reference usually expressed in certain forms of address which will include no comparison of the ranking of the speaker and addresse. For examples: your highness, Mr. President, your majesty, etc.

Briefly, social deixis is a deictic expression used to distinct social status. Social deixis separated in to two kinds relational and absolute social deixis.

\section{e. Discourse deixis}

Discourse deixis deals with the orientation in the text through the writer or the speaker, the relation of the text passages to the current utterance either as a head of time or past, forthcoming or simultaneous. It encodes reference to portions of the unfolding discourse in which the utterance is located (Levinson, 1983, p.62). It means that discourse deixis is deictic reference to a portion of a discourse relative to the speaker's current location in the discourse,

such as: above, below, last, previous, proceeding, next or following (usually used in texts) and this, that, there, next, last (usually used in utterances). 
In spoken or written discourse, there is frequently occassion to refer to earlier or forthcoming segments of the discourse. Since discourse unfolds in time, it is natural to use temporal deictic terms to indicate the relation of the referred to to the temporal location of the present utterance in the discourse. But spatial terms are also often employed. Reference to parts of of a discourse which can only be interpreted by knowing where the current coding or receiving point is, are clearly deictic in character (Asher 1994:856).

Levinson (1983:86) added that discourse deixis should be distinguished from a related notion that of anaphora. Moreover, discourse deixis shares with anaphora and cataphora the capacity to function as a text cohesion device. As we noted, anaphora concerns with the use of a pronoun to refer to the same referent as some prior term. Anaphora can hold within sentences, across sentences, and across at speaking in a dialogue. Deictic or other referring expressions are often used to introduce a referent, and anaphoric pronouns are used to refer to the same entity thereafter. However, it is important to remember that deictic and anaphoric usages are not mutually exclusive. Therefore, in principle the distinction is clear: when a pronoun refers to a linguistic expression itself, it is discourse deictic. When a pronoun refers to the same entity as a prior linguistic expression refers to, it is anaphoric.

In other words, discourse deixis is an expression used to refer to certain discourse that contain the utterance or as a signal and its relations to surrounding text. 


\section{Research Objective}

Based on the background above, the paper only analyzed the scope of pragmatic that focus on deixis in the film entitled "The Good Dinosaurs movie directed by Peter Sohn". This film is an English film that possibly to be analyzed the language used for communicating in the film. Thus, the study of this paper will focus to analyze of the research question as follow:

1. What are types of deixis found in the movie of The Good Dinosaur?

2. What is the most dominant deixis found in the movie and the analysis?

\section{Research Methodology}

The research will present some data in order to complete the research and will use a descriptive qualitative method to analyze the data because the goal of this method is to describe the facts, characteristics, and relationship of the researched elements. Bogdan and Biklen (1982:37) states that there are five features of qualitative method:

The natural setting is the direct source of data and the researcher is the key instrument in qualitative research; qualitative data are collected in the form of words or picture rather than numbers; Qualitative researchers are concerned with process as well as product; Qualitative researchers tend to analyze their data inductively; How people make sense of their lives is a major concern to qualitative researches. 
In addition, Moleong (1995, p.6) says that qualitative research is descriptive, which means that the analyzed data and its findings are in the forms of descriptions, instead of numbers. Therefore, it is clear why this method is chosen.

A descriptive method will be applied in presenting the data, analysis, and its findings. This method is the most appropriate method because it will systematically and factually describe and illustrate the characteristics and the connection between the phenomena studied (Gay L. R: 1998:34). Descriptive methods is appropriate for this study because the goal of this study is systematically, factually, and accurately describes or illustrates the fact, characteristics and relationship of the researched element.

\section{Discussion \& Finding}

1. The finding data

From those five kinds of deixis, there are the finding data from the Good Dinosaur movie:

a. Personal Deixis

\begin{tabular}{|l|l|l|l|}
\hline Division & $\begin{array}{l}\text { Kind } \\
\text { of Expression }\end{array}$ & $\begin{array}{l}\text { Type } \\
\text { of Pronoun }\end{array}$ & $\begin{array}{l}\text { Number } \\
\text { of Finding Data }\end{array}$ \\
\hline \multirow{4}{*}{ First } & \multirow{2}{*}{ Singular } & I & 81 \\
\cline { 3 - 4 } & & Me & 21 \\
\cline { 3 - 4 } & Myself & 1 \\
\cline { 3 - 4 } & Mine & 0 \\
\cline { 3 - 4 } & \multirow{3}{*}{ Plural } & We & 18 \\
\cline { 3 - 4 } & Us & 1 \\
\cline { 3 - 4 } & & Our self & 0 \\
\hline & Our & 5 \\
\hline Second & & Ours & 0 \\
\hline
\end{tabular}


Deixis Analysis of the Good Dinosaur the Movie

\begin{tabular}{|l|l|l|}
\hline \multirow{5}{*}{ Third } & Yourself & 1 \\
\cline { 3 - 3 } & Yourselves & 0 \\
\cline { 3 - 3 } & Your & 39 \\
\cline { 3 - 3 } & Yours & 2 \\
\hline \multirow{5}{*}{} & He & 4 \\
\hline & She & 3 \\
\hline & They & 9 \\
\hline & Him & 16 \\
\hline & Himself & 0 \\
\hline & Her & 3 \\
\hline & Herself & 0 \\
\hline Total & 304 \\
\hline
\end{tabular}

b. Place Deixis

\begin{tabular}{|l|l|}
\hline Type & Number \\
\hline Where & 9 \\
\hline Here & 0 \\
\hline There & 11 \\
\hline Total & 20 \\
\hline
\end{tabular}

c. Time Deixis

\begin{tabular}{|l|l|}
\hline Type & Number \\
\hline Now & 6 \\
\hline Then & 0 \\
\hline Ago & 0 \\
\hline Later & 0 \\
\hline Soon & 0 \\
\hline Before & 4 \\
\hline Yesterday & 2 \\
\hline Today & 1 \\
\hline Tomorrow & 0 \\
\hline Last day & 0 \\
\hline Last week & 0 \\
\hline Last month & 0 \\
\hline Next week & 0 \\
\hline Next month & 0 \\
\hline
\end{tabular}


d. Social Deixis

\begin{tabular}{|l|l|l|}
\hline Kind & Type & Number \\
\hline Relational & Momma & 15 \\
\cline { 2 - 3 } & Poppa & 16 \\
\cline { 2 - 3 } & Son & 2 \\
\cline { 2 - 3 } & Brother & 1 \\
\hline Absolute & - & 0 \\
\hline \multicolumn{2}{|l|}{ Total } & 34 \\
\hline
\end{tabular}

e. Discourse Deixis

\begin{tabular}{|l|l|}
\hline Type & Number \\
\hline This & 3 \\
\hline There & 1 \\
\hline That & 2 \\
\hline Total & 11 \\
\hline
\end{tabular}

Analysis of Dominant Deixis Used in the Story of the Movie

From the finding data, we can observe the most dominant deixis used in the movie is the personal deixis which completing $80 \%$ of the total deixis found in the movie. We can observe it in the chart below: 


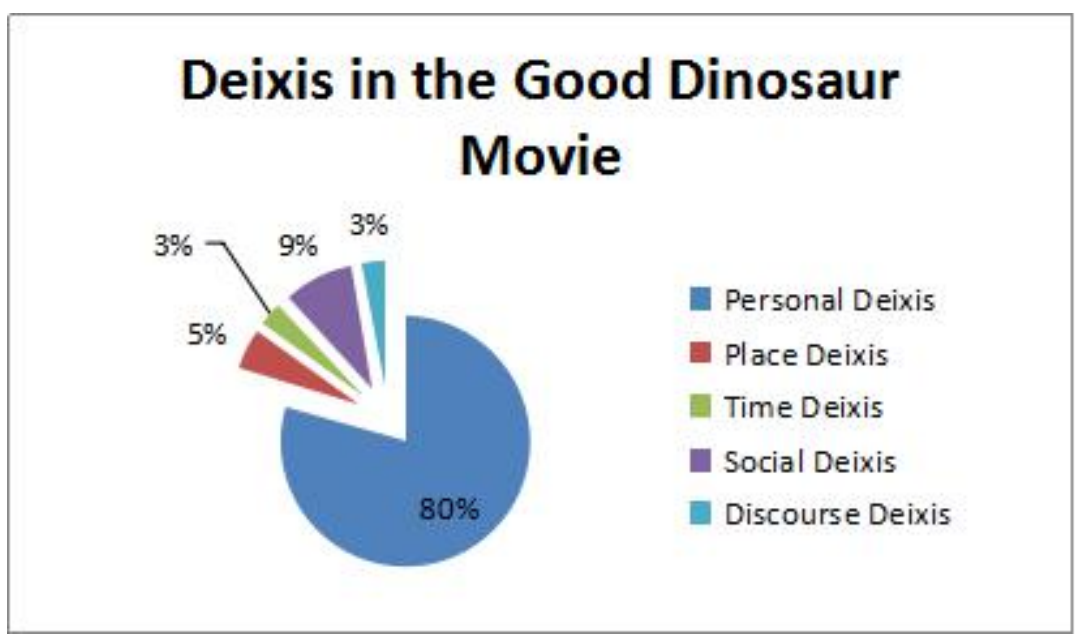

Personal deixis longer we talk about the character of the movie. In this context, the use the author, that is Peter Sohn, asks us to analyze the story from where the author tells it in the context of narrating. This is called as point of view of a story.

Winahyutari (2004:131) stated that point of view is the way the writer shows the story. While Pratiwi (2005:45) argued that showing the point of view is the way to appear the figure or actors in the story. From those definition, we can conclude that point of view is a technique used by author in appearing the character of the story. Moreover, point of view is apparently not only the way to appearing the character, but in the story, most of point of view shows the story about the character, action, set and many occurrences that make the story in some literature.

Abrams in Nurgianto (2002:252) defined there are three kinds of point of view in the story. They are:

1. Third person of point of view

The author is someone who put on his/herself in the outside of the story and show the characters by the name or the pronoun 
such like he, she and they. The name of the character always be mentioned and as a variation there is used the pronominal. This to ease the readers to recognize the characters are being described in the story. The third person of point of view is divided in to two kinds, they are:

a. He/she is the omniscient In this point of view, told from the point of view he/she. Author knows everything deals with characters, events, and actions also motivation which cause the story.

b. $\mathrm{He} / \mathrm{she}$ as an observer

Author describes what the characters see, listen, experience, think and feel.

2. First person of point of view

a. I as the main character

In this point of view, I tells every occurrences and the behavior which "I" experience well internal or external conflict of the "I". Here, "I" becomes the focus of the story which every single event that has a relation towards $\mathrm{I}$ is told by.

b. I as an additional character

In this point of view, I arises not as the main character, but as an additional character. I appears to bring the story towards the readers, while the characters of the story are allowed to brim their self in the story to tell their experiences in the story.

3. Mixed point of view 
Mixed of point of view is the mix of both first and third of point of view.

From those explanations, we can analyze the point of view used in the movie of The Good Dinosaur which mainly use the mention of the name of the characters of the story and directly use a face-to-face conversation, in the film use the third person of point of view. Even, basically the movie uses the third person point of view, however, in the following story the character always uses the first of point of view to describe their own experience as a variation of the story. It proved by the use of the personal deixis which also use the first pronoun. Now let us compare the use of the first, second and the third person used in the movie.

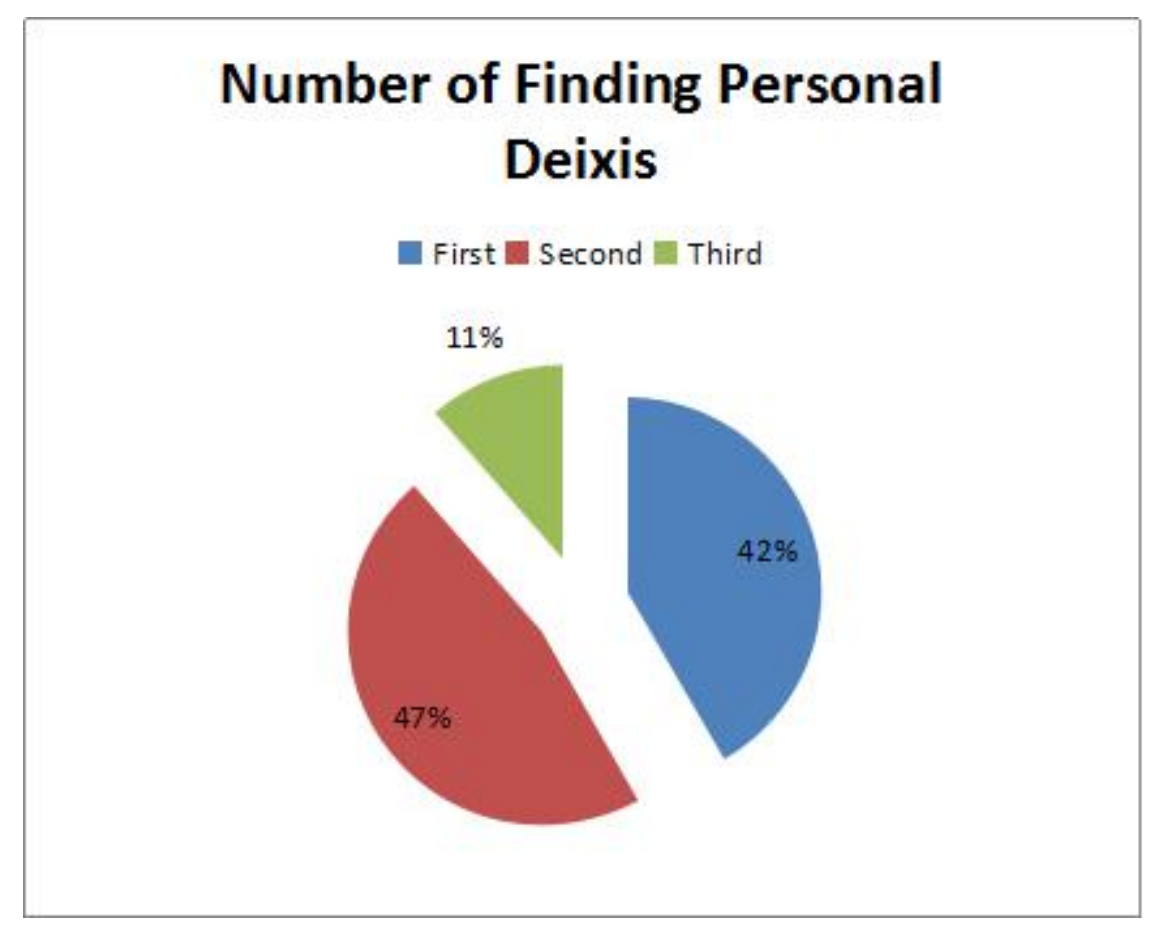


Second personal is also dominate in the chart above, but as we know, in the third person of point of view, the second personal pronoun is used as the opposite of the first personal pronoun. It describes the plot of the story which also deliberating another character that influencing each other. This might the real dialogue becomes real or "lifelike" in the story and also make the readers deliberated to show directly to the conflict which faced by the characters. So when we combine both of first and second personal pronoun and compare it to the third personal pronoun it will be $99 \%$ accordance with $1 \%$. This caused by the dialogues of the movie deliberating the first and second personal pronoun. It can be analyzed from some part of the dialogue that taken as example below:

- Minutes 00:14:24,464 to 00:14:27,133: "I got a new job for you tomorrow."

- Minutes 00:20:51,517 to 00:20:55,189: "but I need you to do more, Arlo."

- Minutes 00:50:37,255 to 00:50:41: “And $I$ said we would get you home."

- Minutes 00:53:37,068 to 00:53:40,305: "How many times I got to tell you this?"

- Minutes 00:58:59,457 to 00:59:03,029: "I know you're there. I can smell you."

This can be combined both of the second personal pronoun with the third personal pronoun and compare it to the first personal pronoun becomes $53 \%$ accordance with $47 \%$. This caused by some of 
the dialogues in the movie deliberating between the third and the first personal pronoun. It means that between the third and the first or conversely has a relationship that make both of personal pronouns used to make a conversation in the movie. This could be analyzed from the example below:

- Minutes 00:11:10 to 670 00:11:15,575 : “Tell Momma I love her."

- Minutes 00:37:08,126 to 00:37:10,869: "I name him, I keep him. Hmm..."

- Minutes 00:57:48,719 to 00:57:52,056: “Ask me what $I$ think they're doing."

- Minutes $01: 12: 34,171$ to $01: 12: 37,808$ : "So $I$ got to go help him."

- Minutes 01:12:38,008 to 01:12:41,214: "Because... I love him."

In brief, it can be said that in the movie, there are two types of point of view used to describe the experiences experienced by the characters of the movie. As the basic, the author use third person of point of view to describe the story by let the characters talk and make a dialogue between the characters by naming her/his self and make a mention of each characters as the variation of using of pronominal.

In this context, the author is also allowing the character to have a direct conversation that could be enjoyed by the readers in case as the viewers. However, in the way the characters play their role, they also tell $\mathrm{him} / \mathrm{herself}$ and sometime tell others by combining both of first and second and second and third personal pronoun. As the 
developing of the story, this is allowed in a story to add the pursue essence of the movie could be longer enjoyed by the viewers.

\section{Conclusion}

Based on the data presentation and data analysis of deixis used in Good Dinosaur the movie, the writer draws some conclusion as follows:

1. Five types of deixis are found in the movie of The Good Dinosaur. They has different number of finding data which the percentages are: personal deixis $80 \%$, place deixis $5 \%$, place deixis $3 \%$ social deixis $9 \%$, and discourse deixis $3 \%$.

2. The huge number of deixis and will be the most dominant deixis found in the movie of The Good Dinosaur is Personal deixis which accumulated $80 \%$ of total deixis. Personal deixis could be the most dominant deixis used in the movie because of it deals with the point of view where there, between the finding data and the point of view meet the correlation. First and second personal pronoun and second and third personal pronoun can built a story way which both of them influences the finding data that deploy the personal deixis to be the most dominant. 


\section{References}

Berger, John. 2008. Ways of Seeing. UK: Penguin.

Cutting, Joan 2002. Pragmatics and discourse. A resource book for students.London: Routledge.

Keraf, Gorys. 1991. Tata Bahasa Rujukan Bahasa Indonesia. Jakarta: PT Grasindo

Leech, Geoffrey. 1983. Principle of Pragmatic. London: Longman.

Mey, Jacob L. 2001. Pragmatics. An introduction. 2nd edition. Oxford: Blackwell.

Moleong, Lexi. 1995. Metode Penelitian Kualitatif. Bandung: Remaja Rosda Karya.

Nurgiyantoro, Burhan. 2002. Teori Pengkajian Fiksi. Yogyakarta: Gadjah Mada University Press.

Pastia, Andi Lisano. 2013. Skripsi Analisis Penggunaan Deiksis Persona Pada Novel Laksamana Jangoi Karya Muharoni.

Yuliana, Nuryati. 2011. Skripsi Analisis Pragmatik Dalam Kartun Editorial "Kabar Bang One" Pada program Berita TV One. perpustakaanuns.ac.id.

Tempo. 2005. Enam Aktivitas Membangun Literasi Sains. Retrieved May 12th, 2016, from https://indonesiana.tempo.co/read/43502/2015/06/09/desibelku.1 /enam-aktivitas-membangun-literasi-sains.

Wikipedia. 2016. Film. Retrieved May 12th, 2016, from https://en.m.wikipedia.org/wiki/film.

Westga.. Introduction: What is Media Literacy?. Retrieved May 12th, 2016, from www.westga.edu/ mmcfar/FilmMedia\%20Literacy.htm 